\title{
Appraising the Performance of Urban Renewal Measures in Nigeria: A Case of Osogbo, Osun State
}

\author{
Adebisi Ilelabayo Ismail \\ Department of Architecture \\ Ladoke Akintola University of Technology, Ogbomoso, \\ Nigeria. \\ Olarinoye John Kehinde, \\ Olaoye Olubunmi Adedayo \\ Department of Architectural Technology \\ Osun State Polytechnic, Iree \\ Osun State \\ Nigeria. \\ Olatinwo Fatai Aderinola \\ Department of Physical Planning and Projects \\ Federal polytechnic, Offa \\ Kwara State \\ Nigeria.
}

\begin{abstract}
The high rate of urban decay which was as a result of uncoordinated urban growth and poor infrastructural planning and provision in Nigeria has informed the need for urban renewal. However, joblessness, displacement, homelessness and hunger among other brunt mostly experienced by the poor dwellers are the direct consequences of past urban renewal programmes. To ameliorate this brunt, certain measures were put in place by the Government before the execution of urban renewal programs recently experienced in Osogbo- the capital of Osun state. This paper hence seeks to appraise the performance of these measures with a view to suggesting possible ways of improving on them. Qualitative and quantitative data were collected for the purpose of the research. Qualitative data was collected through Oral interviews and direct observation. Interviews were conducted on officials of Osun waste management agencies and residents of places where waste disposal on roads was identified to be on a very high scale. Quantitative data was collected using structured questionnaires. A total of 160 questionnaires were administered, 80 of which was administered on selected victims of renewal who lost their shops and places of work and the remaining 80 selected were victims whose residences were affected. Six (6) executed urban renewal measures were identified and appraised and result indicated that only two (2) could be said to have performed. The result also found out that only $42.1 \%$ respondents are aware of more than two of the relief measures put in place, this is an indication of a general low level of awareness of the relief measures taken as against $71 \%$ respondents who claimed they were aware of the urban renewal program long before it was commenced. Appropriate recommendations were given on how to improve on the measures in the future.
\end{abstract}

Keywords: Urban centres, Urban decay, Urban renewal, brunt, Relief measures, cushion effect.

\section{Introduction}

Urbanism revolves around work, play and home [1]. Urban decay occurs when there is a disjoint within these realms of life in cities. Urban renewal measures in city centres are mechanisms to improve blighted traditional sections and 
successfully integrate them with modern developments to ensure viable and economically vibrant environments for the core urban areas of cities at various points in a city's life.

These areas are meant to be the social and economic life blood of cities where commerce and tourism should flourish including the administrative functions and engaging built environment elements that promote exchange of goods, services and information and enlivens the city as it grows [2]. Most viable city centres are densely populated with high rise and closely clustered buildings compared to other parts of the city [3]. Structures and infrastructure in such places are usually old and require continuous use, adaptive reuse, maintenance and updating. But when these urban resources are not well harnessed for appropriate developmental goals amidst the rising teeming population and restrictive planning frameworks, middle and upper class citizens would rather shift to adjourning towns and neighbourhoods especially when they are economically buoyant to own homes in places in dire need of infrastructure and social amenities which are however provided incrementally as the settlement grows organically [3, 4].

Africa and indeed Nigeria is a region experiencing an alarming rate of urban growth, this according to many scholars is as a result of massive rural- urban drift partly due to negligence of rural areas in terms of physical development and governmental interventions and majorly because of the search for better life and office jobs (a distant from strenuous farm jobs) by the rural dwellers [5]. The migration with the attendant shift of city dwellers to urban fringes also creates a strain on resources and infrastructure in city centres which result to slum formations, poor housing conditions, urban blight, infrastructural obsolesce, disaster vulnerability and serious threats to public health $[6,7,8]$.

Urban renewal/regeneration has however been adjudged by many scholars as one of the most effective means of eradicating the challenges of urban decay. This is evident in the works of Authors 5, 7, 9, 10\&11 that all recommended different renewal methods deemed to be capable of tackling the menace of urban decay. Many of these methods have been adopted by different governments in Nigeria. Among was the renewal program experienced in Maroko and Lekki both in Lagos State in 1992 , Oshodi market clearance in 2016 [11], market face-lifting and road expansion experienced in Akure in 2009 [12] and series of renewal programs ongoing in Abuja [7].

Evidently, experiences of past renewal programmes have brought about many positive consequences among which was better public health, well and better planned cities, good and aesthetically pleasing environments, solutions to traffic congestions, attraction of tourists and new business investors, reduction of travel times, reduced slum formations, reduced disorderliness among others [11]. Regeneration or renewal programmes in city centres also rebrand places by upgrading the identity of the place with new urban cultures or revival of existing ones [12].

It is however pertinent to note that as beautiful as the positive consequences may deem to be, urban renewal programs also come with series of negative consequences and severe brunt mostly felt by the poor urban dwellers. Part of which is homelessness, displacement and loss of job experienced by the poor without being compensated [7]. Past renewal programs in Nigeria have also brought about inconvenience due to increased distance from new homes to place of work and schools thereby resulting in increased transport fares or increased trekking time, loss of socioeconomic ties, disconnection with cultural ties, displacement of menial workers etc. [7,11]. The negative consequences of urban renewal programs have caused unending trauma to some parents, leading them to untimely deaths while leaving behind under aged and dependent children to cater all by themselves [11]. Among the few reported cases was the experience of Maroko, Lagos in 1992 which saw many houses destroyed and many properties unaccounted for, leaving the dwellers of Maroko homeless, however, some residents moved to other areas or created new slums elsewhere [13].

Another was the Oshodi market clearance in Lagos experienced in 2016 where most shop owners lose their money and businesses without being compensated [7] In order to ameliorate the severe brunt resulting from urban renewal, certain measures were recently been put in place by the governments before embarking on the program. These measures are believed to be capable of providing sufficient cushion so that the inhabitants of areas to be renewed will 
not be severely affected negatively. Moreover, urban renewal programmes have to be more comprehensive and align with local and regional plans and strategies.

Some of these measures were put in place by the government of the state of Osun before the commencement of the last renewal program experienced in Osogbo-the state capital. These measures include: 1. Monetary compensations given to victims whose dwellings were to be demolished, 2. Development of Zonal and local government headquarters so that immigrants affected in the capital city could return home with less difficult lives ( this is also an attempt to decongest the capital city), 3. Establishment of new towns at Dagbolu, Oba and other fringes of the city, 4. Creation of new markets such as Ayegbaju International market, Aje International market etc. 5. Establishment of mega schools, 6. Creation of central waste disposal systems etc. [11, 19]. But whether these measures provide the desired cushion they were designed for or not remains a question no scholar have answered.

It is however of note that most scholars have focused on suggesting different ways of ameliorating the brunt with little or no attention paid on how effective and sustainable the measures are and their corresponding impact on the Architecture of the urban centres [7]. This study is hence an attempt to evaluate the performance of the urban renewal measures put in place in Osogbo- the capital of the state of Osun with a view to examining how effective the interventions had been in improving the urban environment and impacting the life of the citizens at the time of the study.

\section{STUDY AREA: Osogbo, Osun State.}

Situated on Latitude $7.78^{\circ} \mathrm{N}$ and longitude $4.54^{\circ} \mathrm{E}$, Osogbo is the capital city of Osun State and the administrative headquarter of both Olorunda and Osogbo local governments. The city became the capital of Osun State in 1991 following the creation of the state from Oyo state [16]. The population of Osogbo according to the 2006 population census was 287,156 and was expected to hit 438,516 by 2011 [15]. The town covers approximately 241.79 square kilometers [15].

Since its proclamation as the state capital, Osogbo has witnessed tremendous urban growth and urbanization, owing to the concentration of administrative centres, establishment of industries and increase in population as a result of influx of people from neighboring towns and villages [17].

However, unlike the increase in growth and population, the city has not witnessed a corresponding increase in housing and infrastructure growth. Like other several cities in Nigeria. The uncoordinated increase in population coupled with static growth of housing and infrastructural development has resulted in serious decay of the city centre thereby hampering the quality of the environment and life of its occupants [5].

Between 1991 and 2007, there was no reported urban renewal program in the capital city, the implication of this was the massive decay witnessed in the state. Part of which was the series of recorded yearly flooding that claims lives and properties, congestion and traffic jams on roads, dilapidated infrastructural facilities, derelict school structures and dilapidated primary health centres $[17,19]$.

The high decay rate however called for a compulsory renewal in order to give a facelift to the city and improve the wellbeing of its occupants. While most renewal programs in the country leave affected victims to bear the brunt without compensation, the renewal program embarked upon in Osun state seems to come with some new and positive insights targeted at providing cushion against the negative consequences of urban renewal.

It is however worthy to examine the performance of these measures.

\section{Methodology}

Qualitative and quantitative data were collected for the purpose of the research. Qualitative data was collected through Oral interviews and direct observation. Interviews were manually recorded and digital camera was used to capture images of interest that could assist the course of the research. Quantitative data was collected using structured 
questionnaires. Interviews were conducted on officials of Osun waste management agencies and residents of places where waste disposal on roads was identified to be on a very high scale. These areas include: Igbona, Otaefun, Ajewole, Alabameta, and Kobongbogboe.

80 questionnaires were administered on selected traders seen trading by the road sides at Nelson Mandela Freedom Park, Old garage and Ajegunle, Osogbo. These traders were purposively selected in order to ensure that respondents are victims of renewal who saw their shops and offices cleared during the last renewal program. Out of the 80 questionnaires administered, only 72 representing $90.0 \%$ was retrieved. These set of respondents were expected to answer question sections that borders on their awareness of the established new markets as a relief measure taken by the government, why they prefer trading/hawking beside roads and their general perception of and satisfaction with the renewal project.

Another 80 questionnaires were administered on purposively selected victims of renewal that saw their places of residence either totally or partially demolished, these areas include: Ayetoro, Omo west, Iludun and Testing-ground. While some (mostly tenants) were totally displaced, others, (mostly owners) were seen staying in their partially demolished dwellings. Questionnaires were administered on 45 respondents who are owners (landlords) or their representatives and who were seen in partially demolished dwellings, 20 respondents who identified themselves as displaced victims of the renewal program were met in their various new homes in the same community and 15 in similar situations in other communities. The number of respondents sampled was achieved using Snowball sampling technique, that is, data were collected through referrals (asking known respondents or renewal victims of prospective respondents or other victims they knew). These categories of people were expected to answer questions on their awareness of the development of zonal headquarters, establishment of new towns, establishment of mega schools and monetary compensations as relief measures that were put in place for them. Their general perception of and satisfaction with the renewal programs and the renewal measures put in place were also sought. Respondents' satisfaction was based on three point likert scale ranging from 1- Not satisfied, 2- Neutral and 3-Satisfied. All questionnaires in this case were retrieved.

Researcher observations were made as to the development of the established new towns and contacts of 19 respondents were obtained from their beacons and land demarcations locally called "Corner piece" and interviews were conducted on them to know if they were victims of the renewal, when their lands were procured and why they haven't commenced work on them. These data were descriptively analyzed.

\section{Result analysis and discussion.}

The performance of some of the measures adopted by the state government of Osun to cushion the negative consequences of urban renewal were put to test and are discussed below, descriptive method of analyses was used for illustrating the data.

1. Establishment of Central Waste Disposal System: Before the commencement of urban renewal programs in the state, residents dump their solid wastes in nearby rivers and open dumpsites located within neighborhoods [19]. However, in a bid to sustain the environment and make the city centre habitable, the state government embarked on river dredging to clear rivers of debris and blockages and clear open dumpsites deemed to be causing environmental and health hazards. This was however not done without taking some relief measures. As analyzed by Author [19], part of the relief measures adopted include: Creation of Central waste disposal system at Ido Osun, purchase of septic tanks emptier, acquisition of refuse vehicles, establishment of Osun waste management agency- saddled with the responsibility of collecting wastes across the city and encouragement of private waste collection and management agencies. However, thirty (30) days intensive survey around the city centre revealed that road sides and road medians have been turned into refuse dumpsites, obviously for public waste vehicles to carry. These wastes were however left there for days before being evacuated by public waste collectors (see plates $1 \& 2$ ). This has obviously turned the Architecture of the city centre into an obscene state. 
Interviews with residents mostly market women revealed that since their open dumpsites have been cleared and they cannot afford to pay private waste collectors, they resulted in keeping their solid waste by road sides for free public waste collectors to pack. However, as reported by [19], the high rate of wastes dumped on roadsides in several locations across the city centre coupled with the low number of public refuse vehicles is imposing a serious challenge both to the Architecture of the city centre and also to the health of residents. When asked for reasons why septic tanks emptier were no more in use, officials of public waste collector cited abuse by residents as the reason they were packed away.

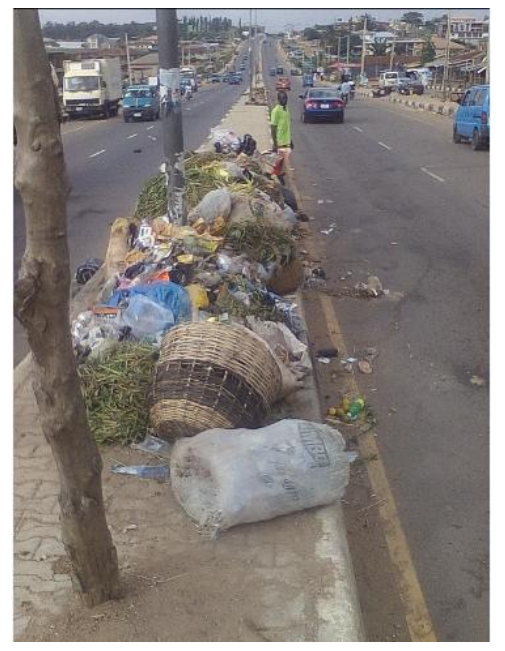

Plate 1: Refuse dumped on road median at Ajewole area, Osogbo.

Source: Authors' field work, 2019.

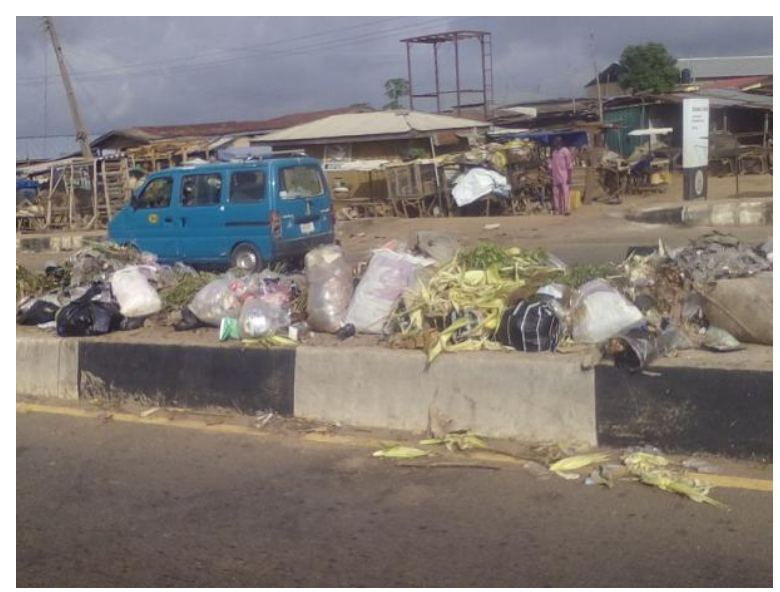

Plate 2: Refuse dumped on road median at Otaefun area, Osogbo.

Source: Authors' field work, 2019.

2. Establishment of New Markets: To cater for those who may lose their shops and business offices as a result of the road dualization and establishment of Nelson Mandela Freedom Park, the state government established two modern markets namely: Aje International market and Ayegbaju International market. Apart from the fact that these markets were strategically located, shops were rented out at very cheap prices.

However, study revealed that most shops in these markets were locked while urban renewal victims were seen trading and hawking beside highways and at other dangerous locations around places where there shops were demolished. To corroborate this, punch newspaper in 2017 reported that the state government of Osun at a press briefing expresses worry over traders' refusal to quit hawking on highways and at dangerous/awkward places despite the establishment of world standard markets. 
The government at the press briefing noted that despite that $95 \%$ of the shops at the markets had been paid for; traders still prefer hawking at road sides around the traditional markets and around places where there shops were demolished. It is however pertinent to note that till date, the situation has not changed. Apart from the fact that the very beautiful and serene environment which was created at the Freedom Park is being negatively affected by the traders' attitude, they are also exposing themselves to road accidents and other forms of urban hazards along road alleys, walkways and easements where their wares are displayed.

Questionnaires were administered on 80 purposively selected traders to know why the new markets were abandoned and only 72 questionnaires, representing $90 \%$ was retrieved. 52 respondents representing $72.2 \%$ reported that the influential middle men were the ones that acquired the shops at a miserable amount of 1,000 Naira (approximately \$2.8) per month from the government and are willing to sublet to them at outrageous prices which they cannot afford. Most traders however put the price demanded by these middle men at 6,000 Naira (\$16.8) per month. 19 respondents representing $26.4 \%$ also reported that they already have established customers at their current location and building a new customer base would take them a lot of time at places where the new markets are located. 1 trader representing $1.4 \%$ cited unavailability of basic amenities as reason for not moving to any of the new markets.

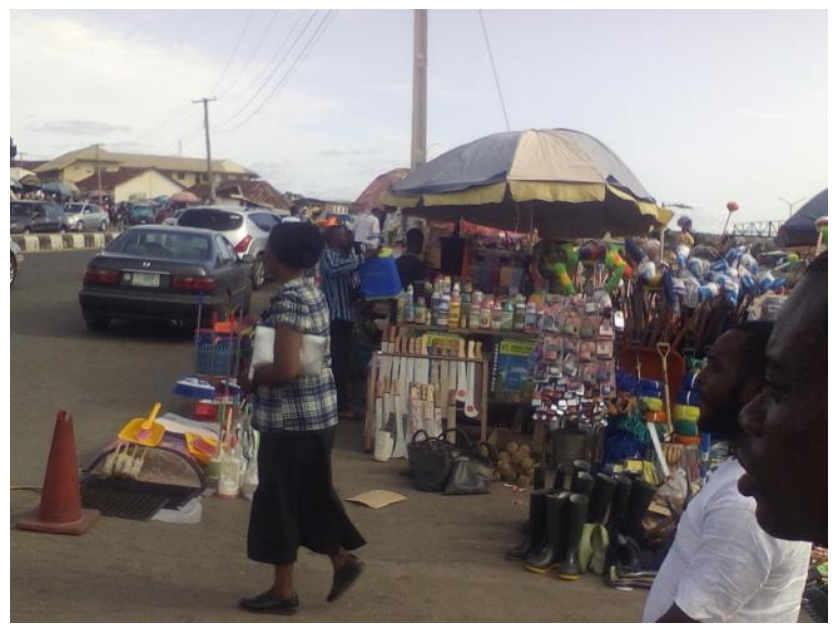

Plate 3: Goods displayed by the road side by traders who lost their shops during the renewal exercise.

Source: Authors' field work, 2019.
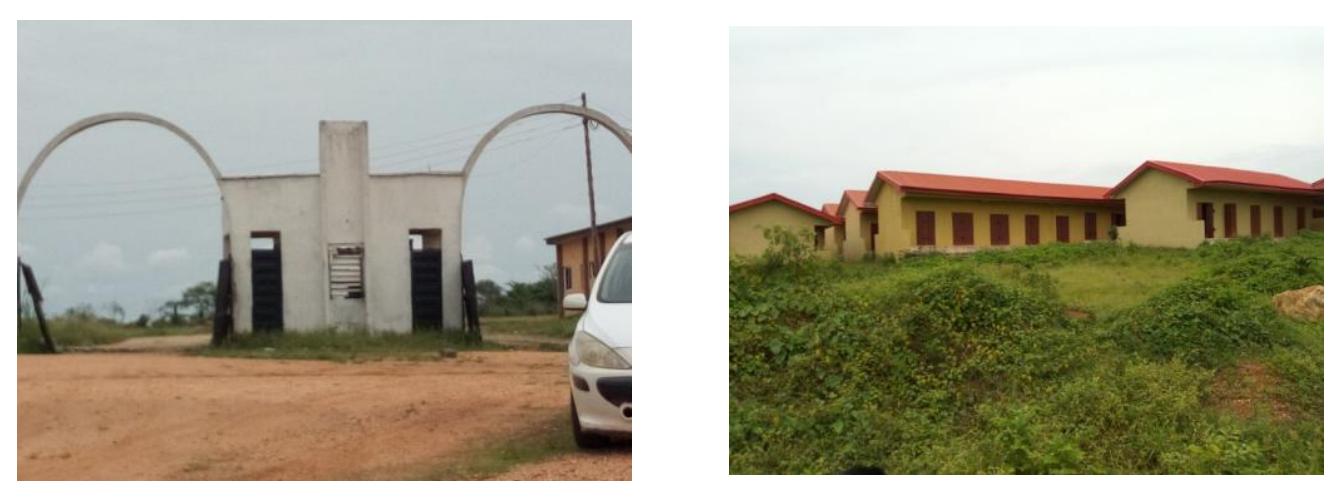

Plates 4\&5: Unoccupied Aje International market Osogbo.

Source: Authors' field work, 2019. 

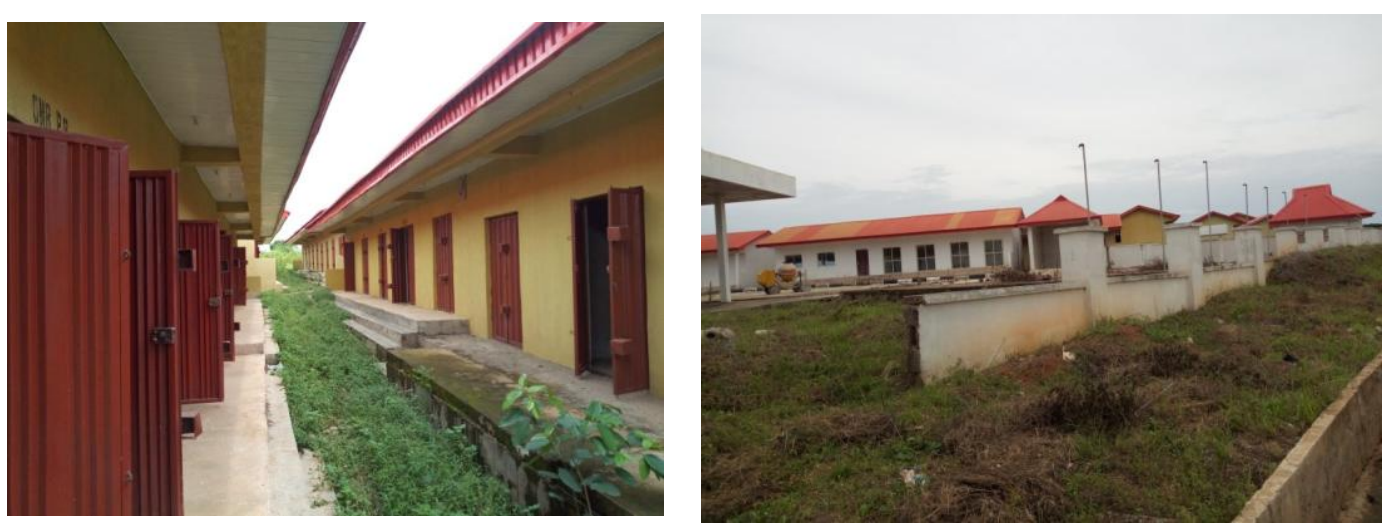

Plate 6\&7: Unoccupied Aje International market Osogbo.

Source: Authors' field work, 2019.

Table 1: Reasons for not moving to the newly established markets.

\begin{tabular}{|l|l|l|}
\hline REASON & NO & PERCENTAGE \\
\hline Established customer base at current location & 19 & 26.4 \\
\hline Cost of rent charged by the government & 00 & 00 \\
\hline $\begin{array}{l}\text { Hiked cost of rent charged by influential middle men who are able to } \\
\text { acquire many spaces from the government and willing to sublet. }\end{array}$ & 52 & 72.2 \\
\hline Security & 00 & 0 \\
\hline Unavailability of supporting facilities and basic amenities. & 01 & 1.4 \\
\hline Total & 72 & 100 \\
\hline
\end{tabular}

Source: Authors' field survey, 2019.

3. Development of Zonal Headquarters. Part of the relief measures embarked upon by the state government before the renewal commenced in the state capital was the development of the zonal headquarters. The zonal headquarters include Ikirun, Iwo, Ila, Ilesa, Ife, Ede etc., this measure was taken in order to make life easy for displaced persons who may wish to relocate to any of their preferred zone to continue their lives and trading activities with less difficult lives. This was also an attempt to decongest the city. Part of the development programs embarked upon in the zonal headquarters includes road construction and rehabilitation, market face lifting, and school rehabilitation. 80 questionnaires were administered on purposive selected respondents who are victims of the renewal exercise and saw their dwellings affected. However, study revealed that most victims prefer to remain in the city. This was justified by $86.3 \%$ of respondents who said they prefer to stay at the city centre than moving to other towns. $69.6 \%$ of those who prefer to stay at the city centre however cited economic prosperity of the capital city over other zonal headquarters while $15.9 \%$ cited social ties with their friends and families as reasons why they find it difficult to move out of the capital city.

Table 2: Choice of relocating to Zonal headquarters

\begin{tabular}{|l|l|l|}
\hline CHOICE & NO & PERCENTAGE \\
\hline *Prefer to remain at the city centre. & 69 & 83.3 \\
\hline $\begin{array}{l}\text { Willing to move to zonal headquarter if } \\
\text { opportuned }\end{array}$ & 06 & 7.5 \\
\hline Undecided & 05 & 6.2 \\
\hline Total & 80 & 100 \\
\hline
\end{tabular}

Source: Authors' field survey, 2019. 
Table 3: *Reason why you prefer to stay at the city centre.

\begin{tabular}{|l|l|l|}
\hline REASON & NO & PERCENTAGE \\
\hline Economic prospects of the city centre & 48 & 69.6 \\
\hline Social ties with friends and families & 11 & 15.9 \\
\hline Religion & 03 & 4.4 \\
\hline Others & 07 & 10.1 \\
\hline Total & 69 & 100 \\
\hline
\end{tabular}

Source: Authors' field survey, 2019.

4. Establishment of New Towns: Well aware that the proposed renewal programs would render some residents homeless, the government acquired lands at strategic locations at the city suburbs. Among was the Osun Country home at Dagbolu Osogbo and Osun Country home along Ikirun Road, Osogbo. The aim was to sell those lands at cheap prices to residents and provide relief measures which would make construction of their buildings relatively easy. Visitation to the sites however revealed that even after seven (7) years of establishment, building construction has not commenced on any of the sites. Though few land demarcations were seen with names and contacts numbers of the buyers on each demarcations. 19 of the land owners were contacted through their various phone numbers to seek their opinions on why they haven't commenced building construction and to know whether they were victims of renewal. All respondents revealed that they were not victims of renewal.

5. Establishment of mega Schools. As part of the measures taken to provide succor to the brunt of renewal programs embarked upon in the state, the state government embarked on the construction of mega schools. This was followed by the reclassification of schools. Apart from the fact that these beautiful structures added value to the Architecture of the capital city, it also brought development to the education sector. Despite outcries at the inception as reported by various media, 56 respondents representing $70 \%$ of those whose dwellings were affected said they were satisfied with the development.

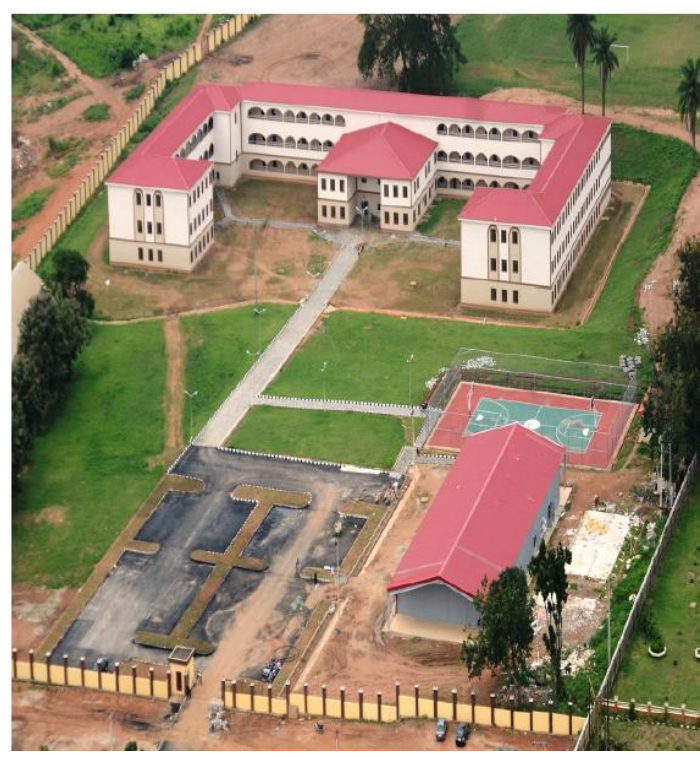

Plate 8: One of the mega schools constructed by the state government.

Source: Reference 16. 
Table 4: Perception of the established mega schools.

\begin{tabular}{|l|l|l|}
\hline PERCEPTION & NO & PERCENTAGE \\
\hline satisfied with the development & 56 & 70 \\
\hline Unsatisfied & 21 & 26.2 \\
\hline Indifferent & 03 & 03.8 \\
\hline Total & 80 & 100 \\
\hline
\end{tabular}

Source: Authors' field work, 2019.

6. Monetary Compensations: Unlike the case of Maroko, Oshodi etc., where victims of urban renewal were not compensated, Urban renewal program embarked upon in Osogbo differs. Data analysis shows that $71.1 \%$ of respondents who claimed to be landlords have received some monetary compensation while no tenant claimed to have received any. This result appears to be in line with the findings of Author [11] who in his findings reported that $68 \%$ of House/ landlords claimed to have received some compensation even though there were outcries in quarters who claimed not to have been received any form of compensation.

Table 5: Victim's Tenure status (Affected residents only)

\begin{tabular}{|l|l|l|}
\hline Victim's Tenure status & NO & PERCENTAGE \\
\hline Landlords & 45 & 56.3 \\
\hline Tenants. & 35 & 43.7 \\
\hline Total & 80 & 100 \\
\hline
\end{tabular}

Source: Authors' field work, 2019.

Table 6: Received some compensation

\begin{tabular}{|l|l|l|l|l|l|l|}
\hline $\begin{array}{l}\text { Tenure } \\
\text { Status }\end{array}$ & \multicolumn{2}{|l|}{ Compensated } & \multicolumn{2}{l|}{ Not compensated } & \multicolumn{2}{l|}{ Total } \\
\hline & No & Percentage & No & Percentage & No & Percentage \\
\hline Landlords & 32 & 71.1 & 13 & 28.9 & 45 & 100 \\
\hline Tenants & 00 & 00 & 35 & 00 & 35 & 100 \\
\hline
\end{tabular}

Source: Authors' field work, 2019.

On a general assessment, while $71 \%$ of all respondents (traders and residents) claimed they were well informed before the renewal programs commenced, only $42 \%$ claimed to be aware of more than two (2) of the relief measures put in place. Establishment of mega schools and new markets, however, top the list of the renewal measure that secured most awareness while establishment of new towns and development of zonal headquarters have the least awareness. $71.1 \%$ of respondents however claimed they were satisfied with the renewal programs that took place in the state, $16.4 \%$ are neutral and only $11.8 \%$ are not satisfied with the program.

Table 7: General assessment

\begin{tabular}{|c|c|c|}
\hline & NO & PERCENTAGE \\
\hline \multicolumn{3}{|c|}{ Total number of respondents } \\
\hline Traders & 72 & 47.4 \\
\hline Residents & 80 & 52.6 \\
\hline Total & 152 & 100 \\
\hline \multicolumn{3}{|c|}{ Respondents awareness of the renewal program before commencement. } \\
\hline Aware & 108 & 71 \\
\hline Unaware & 44 & 29 \\
\hline Total & 152 & 100 \\
\hline
\end{tabular}




\begin{tabular}{|l|l|l|}
\hline Satisfied & 109 & 71.1 \\
\hline Unsatisfied & 18 & 11.8 \\
\hline Neutral/ Indifferent & 25 & 16.4 \\
\hline Total & 152 & 100 \\
\hline \multicolumn{2}{|l|}{} \\
\hline Awareness of cushion/relief measures put in place & 39 & 25.7 \\
\hline Aware of Just one (1) of the relief measures & 49 & 32.2 \\
\hline Aware of Two (2) of the relief measures & 64 & 42.1 \\
\hline Aware of more than Two (2) of the relief measures & 152 & 100 \\
\hline Total & \multicolumn{2}{|l|}{} \\
\hline
\end{tabular}

Source:

Authors' field work, 2019

\section{Conclusion/ Recommendation}

The research work has investigated the performance of the various measures taken to cushion the negative effects of urban renewal programs embarked upon in Osogbo-the capital city of Osun state. Out of the six measures examined, result has clearly shown that only two (2) which are establishment of mega schools and monetary compensations could be said to have performed. It could however be said that the measures put in place still provide some hope for the future of urban renewal programs in Nigeria if well implemented. In view of this, the study came up with the following recommendations believed to be capable of improving the performance of the renewal measures:

1. Public-private initiatives and participatory measures should be embarked upon in the waste management processes in the city.

2. These schemes should cut across all levels of governance and organizational structures within the state to facilitate economic development and constantly maintain a visually appealing and healthy environment.

3. Many studies have indicated the ineffectiveness of public interventions and policies in mass housing provision, however, government should embark on the provision of inventories of housing stocks in cities especially those in traditional centres for participatory upgrading and maintenance with owners and inheritors' of such properties. Maintenance, reuse and upgrading of such properties can be encouraged through property tax rebates and other incentives.

4. New markets, industrial and economic clusters in city centres should be more inclusive through the adoption of existing traders' networks and cooperatives in the development of proposed markets, shopping complexes and malls not just by mere speculation or the use of private developers. The inclusion of these people facilitates their individual and collective engagements and resources and ensures a more sustainable development.

5. The comparative advantages of each zone in the state should be explored and exploited for local and regional developments and developmental synergies. Historical, tourism and cultural sites are to be harnessed to establish related craft based and agro allied industries for the employment of teeming youth in the state including forest reserves in their pristine state for the general development of such places.

6. Incentives and infrastructures to enable people who wish to embark on housing developments in places within the state other than the capital city should be encouraged and facilitated in appropriate communities.

Adequate publicity should be given to these measures even before they are embarked upon especially through extensive consultations with residents and citizens of the state.

\section{Conflict of Interest}

The authors have not declared any conflict of interests. 


\section{References}

[1] Aduwo, E.B., Ewor, P.A. and Ibem, E.O. (2016) Urbanization and Housing for Low-income Earners in Nigeria: Review of Features, Challenges and Prospects, Mediterranean Journal of Social Sciences 7(3)51,347-357

[2] Odufuwa, B.O., J. Fransen, J., Bongwa, A and Gianoli, A. (2009), "Cities, theories and reality", Journal of Geography and Regional Planning Vol. 2(10), pp. 243-248.

[3] Balsas, C.J.L. (2004) Measuring the Livability of Urban Centres: An Exploratory study of Key Performance Indicators, Planning, Practice \& Research79 (1)101-110

[4] Andreasen, M.H., Agergaaard, J. and Moller-Jensen, L. (2016) Suburbanization, homeownership aspirations and urban housing: Exploring urban expansion in Dares Salaam, Urban Studies 1-17

[5] Olotuah, A. O., Aiyetan A.O, (2007) "Appraising the quality of the built environment of Akure, Nigeria", XXXV IAHS World Congress on Housing Science - Melbourne.

[6] Egunjobi, L. (1999), "Our Gasping Cities”, An Inaugural Lecture Delivered at the University of Ibadan on Thursday, 21st October 1999.

[7] Ibem, E.O. (2013), "An appraisal of urban renewal in Nigeria: A case study of the Nigerian Army Shopping Arena, Oshodi-Lagos", Journal of Place Management and Development, Vol. 6 No. 2 pp. 155-170

[8] UN-HABITAT (2010), “The State of African Cities 2010-Governance, Inequality, Urban Land Markets”, United Nations Human Settlements Programme, Nairobi.

[9] Gandy, M. (2006), "Planning, anti-planning and the infrastructure crisis facing metropolitan Lagos", Urban Studies, Vol. 43 No. 2, pp. 371-396.

[10] Fadare, W. and Oduwaye, L. (2009), "Rebranding Lagos through regeneration”, Real CORP 2009 Proceedings Tagungsband, 22-25 April, pp. 780-787.

[11] Agbaje, E.B.A, (2013), "Modernisation, Urban Renewal and the Social Cost of Development", Mediterranean Journal of Social Sciences MCSER Publishing, Rome-Italy.

[12] Hahn, J. (2012), Creative Cities and (Un)Sustainability - Cultural Perspectives (Eds.) Kagan, S. and Bruchi, D. Vol.3

[13] Nwanna, C. (2012) Gentrification in Lagos State: Challenges and Prospects, British Journal of Arts and Social Sciences 5 (2)

[14] Obe, O.J., Okosun, S.E., Ayo-Odifiri, O.S., Omokhafe, C.O., (2017): “Assessment of Urban Market Renewal Projects on the Development of Akure, Nigeria", Journal of Civil and Environmental Research.

[15] Aguda, A.S and Adegboyega, S. A, (2013) "Evaluation of Spatio-Temporal Dynamics of Urban Sprawl in Osogbo, Nigeria using Satellite Imagery \& GIS Techniques”, International Journal of Multidisciplinary and Current Research pp 60-73.

[16] Akinola, S. R (1998), "The pattern of housing quality in Osogbo, Osun State". Ife Journal of Environmental Design and Management, Obafemi Awolowo University, Ile-Ife, 1 \& 2: 109-120 (1998).

[17] Jiboye, A, (2004) ,'The Socio-Cultural Responsiveness of Household Size on Housing Quality In Osogbo, Nigeria", Anthropologist, Vol 6(3, pp 169-174

[18]. Osun Gov. (2017): "Flood Control and Aregbesola's Proactive Steps in Osun". Retrieved from www.osun.gov.ng/2017/09/20/flood-control-aregbesolas-proactive-step-osun-2/

[19] Ministry of Economic Planning, Budget and Development (2018), The State of Osun Development Plan 2019-2028, Taking Osun to a higher Level., Abeere, Osogbo. 